informed that the same insect had been sent in during July from British Columbia where it had been found by Dr. H. G. Dyer, who was collecting for the department.

During a visit to Maine in June, a large number of larvæ of Eucorethra were taken from the spring where the barrel had been sunk. It was noticeable that larvæ of other kinds of mosquitoes were absent, although the adults were very numerous in the immediate vicinity. During the past month many more larvæ have been sent me from the same source.

I found that they were very fond of the larvæ of the different species of Culex and that they ate them, apparently with great relish. On several occasions fourteen Eucorethra larvæ ate, during the night, sixty Culex larvæ out of the seventy that had been placed in the water with them. When eating the larvæ of mosquitoes smaller than themselves, the victim is caught, shaken violently a few times, and swallowed in a few seconds in very much the same way that a pickerel would catch and swallow a smaller fish.

As yet no experiments have been made to see if this new species will devour the larvæ of Anopheles as readily as they will those of Culex. Whether or not this species will thrive in the climate of southern New England is as yet uncertain, but experiments are now being carried on to determine this point.

WM. LyMAN UNDERWOOD.

Mass. Institute of Technology, Boston.

\section{THE ASCENDING OBELISK OF THE MONTAGNE} PELÉE.

Noт the least remarkable of the many extraordinary conditions that have been associated with the recent eruptions of the Martinique volcano is the extrusion of the giant tower of rock, a veritable obelisk, which today dominates the mountain, and which has given to it an added height of 800 to 900 feet. Pelée is no longer 4,200 or 4,428 feet in elevation, but upwards of 5,000 feet. On May 31 last, before it lost 180 feet of its summit, it reached exactly 5,200 feet. This tower of rock, the nature of which was first properly made known by Professor Lacroix, issues di- rectly, and to all intents and purposes verr tically, from the summit of the new cone of the volcano (of whatever precise nature this cone may be) which had been built up in the ancient crateral-basin (the Étang Sec) to a height of 1,600 feet or more, and virtually plugs it. Where it is implanted, it has a thickness of some 300 to 350 feet. From certain points of view the obelisk seems to maintain for most of its height $(800+$ feet) a fairly uniform thickness; from other points it shows a rapidly tapering surface, with a termination in a needle summit, a true aiguille. It is gently curved or arched toward the southwest, or in the direction of Saint Pierre, and on this face it is cavernous or openly slaggy, showing where successive and repeated explosions had carried away portions of the substance. On the opposite side, or toward the east-northeast, the surface appears solid, is smoothed and even polished in part, and shows longitudinal parallel grooves and striæ, very much like glacial markings. On this side it shows plainly the marks of hard attrition, the effect of rubbing upon the encasing rock-the mold, in fact, that determined a portion of the exit-channel.

The constitution of this extruded 'cork' is undeniably lava-a lava whose viscosity or rapid solidification did not permit it to flow over, but which under the giant stress of the volcano simply moved upward, solid from base to summit, and receiving accretions to its mass only from below. The most cursory examination of the relations existing would immediately point to this form of growth and development, but the carefully conducted angle-measurements and observations of contour made by the representatives at two stations of the French Scientific Commission leave no possibility of doubt in the matter, and they further furnish us with data touching the rate of growth. Thus, in eight days preceding June 7 this growth was, as we are informed by M. Giraud, ten meters; and in the four days preceding June 15 (a period within the time of my recent visit to the volcano) it measured six meters. The consideration of the depth to which this giant 
monument descends solid into the volcano would be interesting were there any way of reaching the problem, but for the present there would seem to be none such.

On June 13 last, in company with M. Guinoiseau-one of the observers of the French Commission-I made the ascent of Pelée, and from the immediate crater-rim took a series of photographs of Pelée's singular process, probably the most impressive piece of nature that I had ever seen. The volcano, by comparison with what it had been before, had 'slumbered down to peace,' but yet it was too active to permit us to descend into the crateral-hollow, 300 to 350 feet in depth, that still surrounded the new cone. Steam- and sulphur-puffs were issuing everywhere, and avalanches of rock were repeatedly being disengaged from the obelisk. Pelée was still 'ugly,' and the night before, the southwest base of its crown or plug was glowing with fire-with the liquid lava that was rising in rift-passages. Two days later I noted a feeble line of steam issuing from the absolute apex of the summit, suggesting a continuous passage or channel extending from base to summit. On March 26 a discharge of incandescent balls was observed also to take place from the same position.

Geologists will naturally make a comparison between the Pelée structure and that which was observed to rise in Georgios, in Santorin, in 1867; but the dome of the latter is probably nearer to the cone of Pelée, and suggests little of the obelisk and of its method of formation. And, perhaps, not much more can be said in any comparison that might be made with the 'pyramidated' summits of some of the equatorial volcanoes of South America, whose contours have been given to us by Professor Stübel.

Angelo Heilprin.

Geographical Society of Philadelphia, July 18, 1903.

\section{CURRENT NOTES ON METEOROLOGY.}

HEALTH ON THE ISTHMUS OF PANAMA.

IN a recent number of the Monthly Weather Review (Vol. XXXI., No. 3) General Henry L. Abbot, who has for some years made a special study of the climatological conditions of the Isthmus of Panama, publishes a summary of the climate and health of that district which will prove of general interest at the present time. General Abbot has previously written several discussions of this subject, some notes on which have appeared in these columns. Probably what General Abbot has to say about health on the Isthmus will have the greatest interest just now. Regarding the earlier health statistics, during the construction of the Panama Railroad, it is stated that they ' are well known to have been appalling.' But, as is pointed out, "at that date it was not understood that natives of the temperate regions can not safely perform arduous man; ual labor under exposure to a tropical sun, and that dependence for such work must be placed upon the negroes of the West Indies. White men can supervise, but must not attempt more." The table of "Official Health Statistics' of the Panama Canal, published in the article, may be briefly summarized as follows:

Old Company, 1881-1888, percentage of mortality from disease (European and tropical), 5.97.

Receiver, 1889-1894, percentage of mortality from disease (European and tropical), 2.88.

New Company, 1895-1901, percentage of mortality from disease (European and tropical), 2.61.

The marked improvement shown in recent years is attributed by Dr. Lavoisade, the medical director of the company hospital near Panama, to the better accommodations of the laborers, better drainage, and especially to the fact that the excavations have reached a level below the poisonous emanations of decaying organic matter. For the years 1898-1901 the percentage of mortality from disease was 2.35, which is said not to exceed that on large works in any country. The men herein concerned had, however, been long on the Isthmus. As to yellow fever, the disease most to be feared by unacclimated persons of the white race, during two recent epidemics (in 1899 and 1900), only two cases appeared among the personnel of the company. Dr. Lavoisade believes that yellow fever ' is in no wise necessarily endemic' on the Isthmus. 